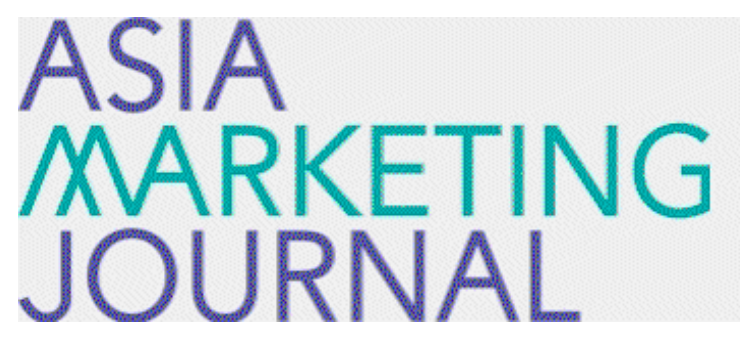

ASIA MARKETING JOURNAL

Volume 6 | Issue 2

Article 2

7-24-2004

\title{
유통업자 브랜드와 제조업자 브랜드 제휴에 대한 소비자 반응연구
}

Seong Do Cho

Gang Ok Jung

Jin Yong Park

Follow this and additional works at: https://amj.kma.re.kr/journal

Part of the Marketing Commons

\section{Recommended Citation}

Cho, Seong Do; Jung, Gang Ok; and Park, Jin Yong (2004) "유톨업자 브랜드와 제조업자 브랜드 제휴에 대 한 소비자 반을연 구," Asia Marketing Journal: Vol. 6 : Iss. 2 , Article 2.

Available at: https://doi.org/10.53728/2765-6500.1125

This Article is brought to you for free and open access by Asia Marketing Journal. It has been accepted for inclusion in Asia Marketing Journal by an authorized editor of Asia Marketing Journal. 


\title{
유통업자 브랜드와 제조업자 브랜드 제휴에 대한 소비자 반응연구 -소재 브랜딩을 중심으로-
}

\section{Consumer Responses to the Alliance between Private Brands and National Brands -Focused on Ingredient Branding-}

\author{
조 성 도(Cho, Seong Do)* \\ 정 강 옥(Jung, Gang $\mathrm{Ok}$ )** \\ 박 진 용(Park, Jin Yong)***
}

기존 연구에서는 주로 유통업자 브랜드와 제조업자 브랜드는 경쟁관계로 보았다. 하지만 본 연구에 서는 유통업자 브랜드가 제조업자 브랜드를 소재 브랜드로 사용하면 유통업자 브랜드에 대한 소비자 들의 저품질 인식올 변화시킬 수 있다는 측면을 이론적, 실증적으로 밝히고자 하였다. 연구결과 유 통업자 브랜드가 제조업자 브랜드를 소재 브랜드로 사용하면 지각된 품질과 구매의도가 향상되는 것 으로 나타넜다. 그리고 제조업자 브랜드와 제품의 일치 정도가 중간일 때 소비자가 가장 긍정적인 반 응을 보이는 것으로 나타났다. 이 관계에서 기능적 위헙이 조절변수 역할을 하는 것으로 나타났는데 기능적 위헙이 높을 때는 소비자들이 유통업자 브랜드와 제조업자 브랜드의 높은 일치성의 경우에 더 좋은 반응을 나타냈으며, 기능적 위헙이 낮을 때는 중간정도 일치할 때 더 좋은 반응을 나타냈다.

핵심개념: 유통업자 브랜드, 소재 브랜드, 브랜드 제휴, 기능적 위헙

\section{I. 서 론}

유통업계에서 유통업자 브랜드는 점점 더 강 력한 마케팅 도구로 부상하고 있다. 유통경로
상에서 할인점, 백화점과 같은 소매상들의 힙이 강해지면서 유통업자 브랜드의 수가 점차적으 로 증가하고 있는 추세이며 유통업자들도 적극 적으로 자체 브랜드를 개발하여 시장 지배력과 협상력을 높이고 매출을 증대 시키려 하고 있

* 전남대학교 경영하부 조교수(matt@chonnam.ac.kr).

** 한남대학교 경영학부 전임강사(gojung@hannam.ac.kr).

*** 동의대학교 유통관리학과 조교수(jypark65@hyomin.dongeui.ac.kr). 
다. 하지만 이러한 유통업자 브랜드도 지속적으 로 성장하기 위해서는 극복해야 할 과제가 있 다. 소비자들이 유통업자 브랜드를 보는 시각이 제한적이기 때문이다. 기존 연구에서는 소비자 들이 유통업자 브랜드의 품질을 신뢰하지 못하 는 경향이 강하고 지각된 위험이 높은 것으로 나타났으며, 구매하는 이유는 저렴하다는 경제 적 이유가 컸다(Richardson, Jain, and Dick 1996: 박진용, 정강옥 2002). 제조업자 촉진과 의 비교연구(Ailawadi, Neslin, and Gedenk 2001) 에서도 유통업자 브랜드 사용은 저렴한 가격이 라는 경제적 동기와 상관관계가 높았고, 제조업 자 촉진을 선호하는 소비자들은 감성적 혜택 (hedonic benefit) 때문에 사용하는 것으로 나 타났다. 이와 비슷한 맥락에서 박진용(2002)의 연구에서는 소매차륜 가설을 활용하여 유통업 자 브랜드의 발전 한계를 설명하였다.

그렇다면 유통업자 브랜드가 가지고 있는 한 계를 극복할 수 있는 방안은 없을까? 이를 위 한 전략 대안의 하나로 유통업자 브랜드와 제 조업자 브랜드간의 제휴가 대두되고 있다. 박진 용(2002)의 연구에서는 소매차륜 가설을 활용 하여 유통업자 브랜드가 지속적으로 성장하기 위해서는 제조업자 브랜드와 제후하는 것이 필 요하고 제휴의 여러 형태와 효과를 컨조인트 분석을 통해 밝히고자 하였다. 일반적으로 유통 업자 브랜드와 제조업자 브랜드는 경쟁관계에 있다고 판단한다. 하지만 경쟁전략 측면에서 제 휴는 상호간의 비용을 절감하고 시장을 확대하 는 장점이 있다. 이와 같은 브랜드 제휴 전략에 는 소재 브랜드를 통한 제휴가 있는데 "intel inside'가 대표적인 예라고 할 수 있다. 최근 학 문적으로도 소재 브랜드를 통한 브랜드 제휴에
대한 연구가 진행되고 있다(Desai and Keller 2002). 따라서 유통업체들이 자체 유통업자 브 랜드가 갖는 한계점을 극복하기 위해 제조업자 브랜드를 소재 브랜드로 사용하여 유통업자 브 랜드 파워를 보다 강력하게 구축할 수 있을 것 이다.

이러한 취지에서 본 연구에서는 다음과 같은 질문에 대해 실증분석 해 보고자 하였다. 유통 업자가 제조업자 브랜드를 소재브랜드로 사용 했을 때 유통업자 브랜드에 대한 소비자 선호 도는 의미있게 증가할까? 제휴 효과가 있다면 어떤 상황에서 유통업자 브랜드와 제조업자 브 랜드의 제휴가 의미가 있을까? 많은 연구에서 제품의 주요 분류로 활용해온 기능적, 감성적 제품에 따라 어떻게 다른 지 알아보고자 하였 다. 또한 소재 브랜드로 사용되는 제조업자 브 랜드가 제품과 어느 정도 일치할 때 소비자가 긍정적인 반응을 나타낼 것인가에 대해 브랜드 확장연구. 스키마 이론. 소재 브랜드 연구 등을 통해 이론적으로 검토하고 실증 분석하고자 했다. 특히, 제조업자 브랜드와 제품의 일치 성에 대한 문제는 중간 일치성 효과(moderate congruity effect)로 설명하였다. 그리고 최근 연구(Campbell and Goodstein 2001)에서는 중 간 일치성 효과와 소비자 선호와의 관계에서 사회적 위험에 초점을 맞추었다. 하지만 본 연 구에서 유통업자 브랜드 상황을 배경으로 기능 적 위험의 조절 효과에 대해 검증하고자 하였다.

본 연구의 목적을 요약하자면 다음과 같다. 첫째, 기존 브랜드 이미지를 가지고 있는 유통 업자 브랜드가 제조업자 브랜드를 소재 브랜드 로 사용했을 때 소비자 반응이 긍정적으로 향 상되는지 실증분석을 통해 알아보고자 한다. 둘 
째, 유통업자 브랜드가 제조업자 브랜드를 소재 브랜드로 사용했을 때 소비자 반응이 기능적 제품과 감성적 제품에 따라 차이가 있는가이다. 셋째 유통업자 브랜드와 제조업자 브랜드가 제 휴할 때 제조업자 브랜드와 제품의 일치성이 소비자 반응에 미치는 영향과 기능적 위헙의 조절 효과를 알아보고자 하였다.

\section{II. 이론적 배경}

\section{1 스키마 이론과 중간 일치성 효과}

소비자가 제품에 대한 정보처리를 하는 과정 을 설명하는 이론 중에 하나가 스키마 이론이 다. 소비자는 제품이나 브랜드에 대해 네트워크 를 형성하고 있는데 이 체계를 스키마라고 한 다. 소비자는 이 스키마를 활용하여 새로운 정 보나 현상을 해석하게 된다. 이러한 해석 과정을 설명하는 데 사용되는 것이 일치성(congruity) 이다. 이러한 이론은 브랜드 확장. 신제품 개발 등의 분야의 현상을 설명하는데 활용되어 왔 다. 상식적으로는 기존 스키마와 일치성이 높 은 정보가 높은 선호도를 나타낼 것으로 판단 되나 기존 연구에 의하면 중간정도의 일치성 (moderate congruity)을 보일 때 소비자 선호 도가 가장 높은 것으로 나타났다(Meyers-Levy and Tybout 1989: Peracchio and Meyers-Levy 1994). 이 연구들에 따르면 소비자는 일치성이 높거나 아주 낮을 때는 인지적 노력을 하지 않 기 때문에 기존 스키마에 따라 쉅게 선호도를 결정하게 된다. 하지만 중간의 일치성을 나타낼
때에는 인지적 노력을 많이 하기 때문에 이 과 정에서 선호도가 상승하게 된다. 다시 말해, 소 비자는 브랜드와 제품 범주간의 일치성이 클 때는 정보처리 과정에서 환기(arousing)가 되지 않아 긍정적인 태도를 보이지 않지만 중간 정 도의 일치성일 때는 불일치를 해결하려는 정보 처리 노력을 하고 이 과정에서 긍정적인 태도 를 갖게 된다는 것이다. 그런데 이러한 중간 일 치성 효과는 모든 경우에 나타나는 것이 아니 라 소비자의 높은 사전지식(Peracchio and Tybout 1996), 높은 독단성(dogmatism) (MeyersLevy and Tybout 1989), 높은 사회적 위헙인 경우에는 나타나지 않고 이 경우에는 도리어 일치성이 높을 때 선호도가 상승하는 것으로 나타났다(Campbell and Goodstein 2001). 특히. Campbell and Goodstein(2001)의 연구에서는 지각된 위헙 중에서 사회적 위헙의 조절 효과 를 실증 분석하였는데 사회적 위헙이 높을 때 는 중간 일치성 효과가 나타나지 않고 도리어 일치성이 높을 때 소비자 선호도가 가장 높은 것으로 나타났다. 중간 일치성 효과는 지각된 위험이 없는 경우에만 나타났다.

\section{2 유퉁업자 브랜드 관련 연구}

유통업자 브랜드와 관련된 연구들 중 많은 연 구들이 소비자가 유통업자 브랜드를 구매하는 데 영향을 미치는 요인들에 대한 연구들이었다 (김성배. 전인수 2002; 박진용, 정강옥 2002: Richardson, Dick, and Jain 1994; Richardson. Jain, and Dick 1996). 기존 연구에서 유통업자 브랜드 구매에 영항을 미치는 주요 변수들은 지각된 위험, 지각된 품질, 지각된 가치 등이었 
다(Richardson, Dick, and Jain 1996). 이 연구 들의 공통점은 소비자들은 유통업자 브랜드의 품질에 대해 의심을 하며 유통업자 브랜드는 전국적인 제조업자 브랜드에 비해 열등하다는 것이었다. 그리고 유통업자 브랜드를 선호하는 이유를 가격대비 품질인 가치로 설명하고 있다. Richardson, Dick, and Jain(1994) 연구에서는 소비자들이 유통업자 브랜드를 평가할 때 내재 적 단서보다는 외재적 단서를 사용하고 있으며 소비자들의 지각된 가치가 유통업자 브랜드 선 호에 중요한 영향을 미친다는 것을 밝혔다.

Vaidyanathan and Aggarwal(2000)의 연구에 서는 알려지지 않은 유통업자 브랜드가 알려진 제조업자 브랜드와 결합했을 때는 지각된 품질 과 선호도가 상승하는 것으로 나타났다. 이 연 구는 유통업자 브랜드와 제조업자 브랜드의 제 휴가 긍정적 반응을 가져온다는 것을 실증했다 는 점에서 의미가 있지만 소비자들이 기존 유 통업자 브랜드에 대해 가지고 있는 이미지를 고려하지 않았다는 한계점을 갖고 있다.

Ailawadi, Neslin, and Gedenk(2001)의 연구 에서는 제조업자 브랜드 촉진과 유통업자 브랜 드는 서로 경쟁관계며 제휴하기 힘든 것인가에 대한 의문을 제기하고 각 브랜드를 사용하는 소비자들에 대한 분류를 시도했다. 연구결과 유 통업자 브랜드는 경제적, 비용측면과 상관관계 가 높고 제조업자 브랜드 촉진은 감성적 혜택 (hedonic benefits) 과 관련성이 높은 것으로 나 타났다. 이 연구는 변수간의 인과적인 관계를 밝히지는 않았지만 유통업자 브랜드와 제조업 자 브랜드가 경쟁 관계가 아니라 제휴할 수 있 는 여지가 있다는 것을 보여주었다는 점에서 의의가 있다. 국내 연구로는 박진용(2002)의 연
구에서는 탐헙적 연구를 통해 유통업자 브랜드 와 제조업자 브랜드가 제휴했을 때 소비자 지 각하는 브랜드 가치가 상승할 수 있음을 컨조 인트 분석을 통해 설명하려고 했다.

\section{3 소재 브랜드 및 공동 브랜드 관련 연구}

$\operatorname{Keller}$ (2002)는 소재 브랜드를 브랜드 연상을 통한 자산 구축에 활용되는 2 차 요소로 구분하 고 있다. Keller(2002)는 2차 연상 레버리지의 중요성을 강조하면서 그 원천으로 기업 이미지, 원산지, 유통경로, 다른 브랜드, 모델, 이벤트를 제시하고 있는데 소재 브랜드는 다른 브랜드에 해당된다. Keller(2002)가 제시하고 있는 다른 브랜드는 브랜드 제휴(brand alliance)를 의미하 는데 브랜드 제휴는 공동 브랜딩(co-branding), 소재 브랜딩(ingredient branding), 광고 제휴 (advertising alliance)로 구분할 수 있다. 공동 브랜드는 LG-IBM과 같이 두개의 브랜드가 공 동으로 사용되는 것을 말한다. 소재 브랜딩은 Intel inside와 같이 제품의 소재나 원료에 다른 브랜드를 사용하는 것을 의미한다. 광고 제휴는 두개의 브랜드가 공동으로 광고하는 것을 가리 킨다. 하지만 실무적으로는 이 세 가지를 명확 하게 구분할 수 있는 것은 아니다. 소재 브랜딩 을 하면서 광고도 같이 하는 경우도 있기 때문 이다. 따라서 소재 브랜딩은 브랜드 제휴의 한 종류로서 공동브랜드, 광고제휴와도 관련성을 갖고 있다.

공동 브랜드 연구와 관련해서 원산지와 브랜 드명이 주어졌을 때 소비자가 어떻게 정보처리 하는지에 대한 연구가 있었다. 이 연구는 공동 
브랜딩의 소비자 정보처리를 설명하는데도 시 사점을 제시해 준다(Lee and Ulgado 1994). Lee and Ulgado(1994)는 브랜드명과 원산지가 동시에 주어졌을 때 소비자들이 어떤 반응을 나타낼 것인가에 대한 실험연구를 하였다. Lee and Ulgado(1994)는 '멕시코에서 만들어진 혼 다 자동차'와 같은 메시지 형태로 원산지가 긍 정적, 부정적인 경우와 브랜드명이 긍정적, 부 정적인 경우를 놓고 $\mathrm{TV}$ 와 운동화를 대상으로 실헙 연구를 하였다. 연구결과 소비자들은 브랜 드명만 가지고 전체적인 평가를 하는 것으로 나타났다. 이 연구의 목적은 소비자들이 원산 지 정보와 브랜드명을 동시에 접했을 때, 두 개의 단서를 모두 사용하는 범주 통합(category integration) 정보처리, 하나의 단서만을 사용하 는 하위 항목화(subtyping) 정보처리, 속성 정 보처리(piecemeal elaboration) 중에서 어떤 것 을 사용할 것인가를 확인하는 것이었다. 연구결 과 브랜드명을 중심으로 하위 항목화 정보처리 를 하는 것으로 나타넜는데 그 이유를 명확하 게 제시하지는 않았다. 이 연구의 방법은 'Sony TV set manufactured in Taiwan'과 같은 형태 로 정보가 전달되었는데 이는 Park, Jun, and Shocker(1996)의 연구에서 브랜드가 주브랜드 (header)냐 수식 브랜드(modifier)냐에 따라 브 랜드가 미치는 영향이 다르다는 주장을 고려하 면 추가로 연구되어야 할 여지가 많다.

Park, Jun, and Shocker(1996)는 결합 브랜드 확장(composite brand extension)이란 개념을 제시하고 실증 연구하였는데 이론적 기반은 심 리학의 개념 특성화 모델(concept specialization model)에 두고 있다. 개념 특성화 모델은 형용 사와 명사, 명사와 명사가 결합되었을 때 어떻
게 정보처리를 하는가에 대한 것으로써(Cohen and Murphy 1984) 브랜드 확장 시에 두 개의 단어 중에서 주브랜드(header)일 경우에 수식 브랜드(modifier)보다 큰 영향력을 행사하는 것 으로 본다. Park, Jun, and Shocker(1996)는 명 사와 명사의 단어 결합을 활용하여 두 개의 브 랜드가 결합해서 새로운 제품 영역으로 진출했 을 때 각각의 브랜드가 새로운 제품 개념에 어 떤 영향을 미치는 지 실증하였다. 연구결과 두 개의 브랜드 중 한 브랜드의 속성이 더 두드러 지고(salient) 성과가 좋은 것으로 지각되면 확 장 브랜드에서도 동일한 지각 현상이 일어나는 것으로 나타났다. 그리고 그 효과가 주브랜드 (header)일 경우에 보다 강력하게 일어나는 것 으로 나타났다. 하지만 주브랜드(header)와 수 식브랜드(modifier)가 서로 보완적이더라도 확장 브랜드에 반드시 긍정적 영향이 미치지는 않는 것으로 나타났다. 그러나 수식브랜드(modifier) 가 주브랜드(header)와 보완적이면 주브랜드에 는 긍정적 피드백 효과가 있는 것으로 나타났다.

Desai and $\operatorname{Keller}(2002)$ 는 소재 브랜딩을 해 서 새로운 제품 영역으로 확장할 때 어떤 전략 을 사용할 지 제시하였다. 연구결과 브랜드 확 장에서 기존 제품 범주 내에서 간단한 속성을 추가할 때(slot-filler expansions)는 자체 제품 지향 소재 브랜드(self-branded ingredient) 가 효과적이고 완전히 새로운 영역으로 진출할 때 는 공동 소재 브랜드가 좋은 것으로 나타닜 다. 이 현상을 스키마 태그 첨가 모델(schemaplus-tag model)과 하위 항목화 모델(subtyping model)로 설명하고 있다.

Venkatesh and Mahajan(1997)은 소재 브랜 딩을 했을 때 소비자가 지불하려고 하는 가격 
의 프리미엄이 나타나는 것을 'intel inside'와 'compaq'의 결합을 통해 밝혔다.

이와 같이 공동 브랜드와 관련된 연구들은 상 황에 따라 다양하게 진행되고 있다. 그런데 김 현경, 이문규(2003)의 연구에서는 두 개 브랜드 의 공동 브랜드 상황을 모두 고려하여 상황에 따라 다른 이론적 설명을 시도하였다. 동화-대 조효과, 하위 항목화, 중간일치성 효과 등으로 다양한 브랜드 제휴 효과를 설명하고자 하였다. 특히, 두 개 브랜드의 일치성을 두 개의 범주 로 나누어 기술적 일치와 평가적 일치로 나누 어 분석하고자 하였다. 기술적 일치(descriptive consistency)는 제품 범주에서의 일치를 말하고 평가적 일치는 브랜드 단위에서의 일치를 말한 다. 이 연구의 상황이 모든 브랜드 제휴 상황을 완벽하게 설명하고 있지는 않지만 공동 브랜드 에서 일치성을 중요시하고 소비자 반응을 연구 하였다는 점에서 의미가 있다.

\section{III. 연구가설}

공동 브랜드의 형태는 여러 가지가 있을 수 있다. 박진용(2002)의 연구에서는 제조업자 브 랜드와 유통업자 브랜드의 제휴 형태를 인지도 추가, 보완성 강화, 신뢰도 증가. 신규성 연상으 로 구분하고 소재 브랜드를 사용하는 것은 신 뢰성 증가로 분류하였다. 본 연구에서는 여러 전략적 연계 유형 중에서 유통업자가 신뢰도 증가를 위해 소재 브랜드를 사용하는 것에 초 점을 맞추고자 하였다.

박진용(2002)의 연구에서는 할인점 유통업자
브랜드가 제조업자 브랜드와 결합하였을 때는 소비자가 지각하는 부가가치가 상승한다고 하였 다. 그리고 Vaidyanathan and Aggarwal(2000) 의 연구에서는 전혀 알려지지 않은 유통업자 브랜드가 제조업자 브랜드와 결합하였을 때는 소비자의 선호도가 상승한다고 하였다. Ailawadi, Neslin, and Gedenk(2001)는 유통업자 촉진과 제조업자 촉진이 서로 경쟁관계에 있는 것이 아니고 유통업자 촉진은 경제적 가치, 제조업자 촉진은 감성적 가치의 비중의 크다고 하였다. 이러한 관점에서 제조업자 브랜드가 유통업자 브랜드의 소재 브랜드로 사용될 때 신뢰성을 높이는 작용을 할 수 있을 것이다. 소비자들은 유통업자 브랜드에 대해 비용측면의 이점을 고 려하지만 품질에 대한 확신을 가지고 있지 못 하기 때문에 기존 이미지가 분명한 유통업자 브랜드의 경우에도 제조업자 브랜드와 제휴하 였을 때는 소비자 선호도가 증가하게 될 것 이라는 것을 예상할 수 있다. 김현경, 이문규 (2003)의 연구에서는 단순히 두 브랜드가 결합 하는 상황을 가정하고 다양한 형태의 브랜드 제휴 효과가 나타날 수 있다고 하였다. 하지만 제품 품질의 신뢰성이 중요한 유통업자 브랜드 의 경우에는 소재 브랜드의 효과가 다른 형태 의 브랜드보다 긍정적인 효과를 유도할 가능성 이 많다고 할 수 있다. 유통업자 브랜드가 아닌 제조업자 브랜드의 소재 브랜딩 연구에서도 소 재 브랜드를 사용하였을 때 가격 프리미엄이 나타났다(Venkatesh and Mahajan 1997). 이상 과 같은 논의를 기초로 본 연구에서는 다음과 같은 가설을 제시하였다.

가설 1: 유통업자 브랜드가 제조업자 브랜드 
를 소재 브랜드로 사용하면 소비자 의 지각된 품질과 구매의도가 증가 할 것이다.

기존 연구에서 유통업자 브랜드에 대한 소비 자들의 선호는 저렴한 가격으로 기본적인 기능 을 갖춘 제품을 구매할 수 있다는 동기에서 출 발하지만 기능적인 품질에 대해서는 의심하는 것으로 밝혀겼다(Richardson, Dick, and Jain 1994: Richardson, Jain, and Dick 1996). 그런 데 Ailawadi, Neslin, and Gedenk(2001)는 제조 업자 브랜드 촉진과 유통업자 브랜드 촉진이 서로 경쟁관계에 있는 지 소비자 가치를 기준 으로 분석하였다. 연구결과 제조업자 브랜드와 유통업자 브랜드를 사용하는 소비자 가치는 서 로 다른 것으로 나타났다. 유통업자 브랜드 촉 진을 선호하는 소비자들은 주로 경제적 혜택 측면을 고려하고 제조업자 브랜드 촉진을 선호 하는 소비자들은 감성적 혜택을 추구하는 것으 로 나타났다. 이처럼 유통업자 브랜드는 경제적 혜택의 장점이 있지만 품질에 약점이 있으며 유통업자 브랜드와 제조업자 브랜드가 경쟁관 계만은 아니고 제휴의 여지가 있음을 알 수 있 다. 그런데 Park, Jun, and Shocker(1996)의 연 구에서는 두 개 브랜드의 제휴를 설명하면서 주된 브랜드의 효과가 더 강력한 영향을 미친 다고 주장하였다. 김현경, 이문규(2003)의 연구 에서도 공동 브랜드의 일치성을 설명하면서 제 품군 단위의 기술적 일치성과 이보다 낮은 단 계의 브랜드 일치성인 평가적 일치성을 제시하 였다. 본 연구의 유통업자 브랜드가 제조업자 브랜드를 소재브랜드로 사용하는 경우에서도 유통업자 브랜드와 제품군과의 일치성이 기술
적 일치성이라고 할 수 있다. 이 일치성은 소재 브랜드의 일치성보다 한 단계 높은 일치성으로 Park, Jun, and Shocker(1996)가 제시한 주브 랜드(header) 효과 때문에 소재 브랜드의 이미 지보다 강력한 영향을 미칠 것이다.

그런데 기능적 제품인 유통업자 브랜드에 품 질단서로 작용하는 소재 브랜드가 사용되면 감 성적 제품일 때 보다 더 강력한 단서로 작용할 가능성이 크다. 왜나하면 유통업자 브랜드는 품 질에 대해서 의심받고 있고 이 의심은 기능적 제품에서 더 크게 나타날 것으로 예상되므로 품질 단서가 되는 소재 브랜드가 보완작용을 할 것이기 때문이다. 제조업자 브랜드가 소재 브랜드로서 유통업자 브랜드를 보완할 때 유통 업자 브랜드의 저품질 이미지가 더 심각하게 부각되는 기능적 제품일 때 더 큰 보완효과를 줄 가능성이 크다는 것이다. 이상과 같은 배경 에서 본 연구에서는 다음과 같은 가설을 제시 하였다.

가설 2: 유통업자 브랜드가 제조업자 브랜드 를 소재 브랜드로 사용했을 때 기능 적 제품인 경우가 감성적 제품인 경 우보다 지각된 품질과 구매의도가 더 크게 증가할 것이다.

김현경. 이문규(2003)의 연구는 두 개의 브랜 드명을 제시하는 연구를 통해 다양한 공동 브 랜드 현상을 설명하고자 하였다. 본 연구에서 유통업자 브랜드가 주브랜드로서 제품군과 일 치하는 정도는 기술적 일치성이라고 할 수 있 으며, 제조업자 브랜드가 유통업자 브랜드의 품 질을 보완하기 위한 단서로써 소재 브랜드로 
사용되는 경우는 평가적 일치성에 가깝다고 할 수 있다. 그리고 본 연구의 상황인 소재 브랜드 로 사용되는 제조업자 브랜드와 제품과의 일치 성은 김현경, 이문규(2003) 연구에서 제시한 이 론적 설명 중에서 시너지 효과가 나타날 가능 성이 크다. 품질의 보완이 필요한 유통업자 브 랜드의 경우에(박진용 2002) 제조업자 브랜드 가 소재 브랜드로 사용되면 공동 브랜드에 대 한 소비자 평가는 한 브랜드로 전체를 평가하 는 동화나 대조 효과가 일어나기보다는 시너지 효과가 나타난다는 의미이다.

그런데 기존 이론(Mandler, 1982: MeyersLevy and Tybout 1989: Peracchio and Tybout 1996)에 비추어 볼 때 시너지 효과는 제조업자 브랜드와 유통업자 브랜드가 중간정도 일치할 때 가장 긍정적으로 나타난다고 추론할 수 있 다. Meyers-Levy and Tybout(1989)는 제품속 성 정보와 소비자가 가지고 있는 스키마와 어 느 정도 일치할 때 기억이 증가하는 지 연구하 였는데 중간정도 일치할 때 가장 많은 정보처 리 노력을 하고 기억도 증가하는 것으로 나타 났다. Mandler(1982)의 주장을 구체적으로 설 명하면 기존 스키마가 있고 새로운 정보가 주 어졌을 때 새로운 정보와 기존 스키마가 중간 정도 불일치할 때 소비자는 가장 적극적으로 정보처리를 하고 이 과정에 기억이 증가하고 문제해결 후의 선호도도 가장 높게 상승한다고 하였다. 따라서 본 연구 대상인 소재브랜드로 사용된 제조업자 브랜드와 제품의 일치성 정도 도 유사한 현상이 나타날 것으로 예상할 수 있다.

그러나 기존 연구에서는 이러한 중간불일치 효과가 언제나 일어나지 않는 것으로 나타났다
(Meyers-Levy and Tybout 1989; Peracchio and Tybout 1996: Campbell and Goodstein 2001). Meyers-Levy and Tybout(1989)의 연 구에서는 독단성(dogmatism)이 중간일치성 효 과의 조절변수 역할을 하는 것으로 나타났다. 구체적으로 말하면 독단성(dogmatism)이 높은 소비자들에게는 중간일치성 효과가 나타나지 않는 것으로 나타났다. 그리고 Peracchio and Tybout(1996)의 연구에서는 소비자의 사전지식 에 따라 중간일치성 효과가 다르게 나타났다. 초보자의 경우는 중간일치성이 그대로 나타났 으나 전문가의 경우는 중간일치성 효과가 나타 나지 않고 가지고 있는 스키마에 근거해서 정보처리하는 것으로 나타났다. Campbell and Goodstein(2001)은 이러한 조절변수로 지각된 위험을 연구하였다. 고급 포도주를 평가하는 상 황으로 사회적 위험이 중간일치성 효과에 어떤 영향을 미치는 지 알아보고자 하였다. 사회적 위헙만을 연구한 것은 제품 성격과 구매상황과 밀접한 상관이 있다고 볼 수 있다. 연구결과 사 회적 위험이 높은 경우는 일치성이 높은 경우 가 선호되었고, 사회적 위헙이 낮을 때에만 중 간일치성 효과가 나타났다. 이러한 기존 연구를 볼 때 본 연구의 대상인 유통업자 브랜드와 제 조업자 브랜드의 제휴에 따른 소비자 평가에서 중간일치성 효과도 조절변수에 의해 영향을 받 는다는 것을 예상할 수 있다. 특히, 유통업자 브랜드는 품질에 의심을 받는 경우가 많고 지 각된 위헙이 중요한 영향변수 임이 밝혀진 것 을 볼 때. Campbell and Goodstein(2001)의 연 구가 중요한 시사점을 제공해 준다. 그런데 본 연구의 대상인 소재브랜드는 제품의 기능과 밀 접한 관련이 있으므로 지각된 위험 중에서도 
기능적 위헙이 중요한 역할을 할 것으로 예상할 수 있다. 다시 말해. 기능적 위헙이 유통업자 브 랜드와 소재 브랜드로 사용된 제조업자 브랜드 제휴의 평가에 영향을 주어 중간일치성 효과를 조절할 가능성이 크다. 기능적 위험이 클 때와 낮을 때 중간일치성 효과가 영향을 받을 것이 다. 본 연구에서는 이상과 같은 논의 바탕으로 다음과 같이 가설 3 , 가설 4 를 제시하였다.

가설 3: 기능적 제품의 유통업자 브랜드가 제 조업자 브랜드를 소재 브랜드로 사용 할 때 기능적 위헙이 높을 경우에는 제조업자 브랜드가 제품과 일치하는 정도가 높을 때가 중간정도 일 때보 다 더 긍정적인 지각된 품질과 구매 의도를 나타낼 것이다.

가설 4: 기능적 제품의 유통업자 브랜드가 제 조업자 브랜드를 소재 브랜드로 사용 할 때 기능적 위험이 낮을 경우에는 제조업자 브랜드가 제품과 일치하는 정도가 중간 정도일 때가 일치성이 높을 때보다 더 긍정적인 지각된 품 질과 구매의도를 나타낼 것이다.

\section{IV. 연구방법}

\section{1 실험 설계 및 대상}

본 연구는 실험을 통해 가설을 검증하였는데 가설 1-4를 검증하기 위한 전체적인 실험설계 의 틀은 〈표 4-1〉과 같다. 〈표 4-1〉에서 보는
것처럼 혼합 실험 설계를 사용하였는데 소재 브랜드 유무와 제품 유형. 기능적 위험의 높 고 낮음, 일치성의 고, 중에 따른 집단간 설계 (between subject design)를 사용하여 팩토리 얼 디자인을 사용하였다. 가설은 계획된 대조 (planned contrast)에 따라 가설별로 집단을 대 비시켜 비교하는 방법으로 검증하고자 하였다. 실험설계에서 일치성의 고 중만 고려하고 매우 불일치는 포함하지 않은 이유는 매우 불일치는 기존 연구 결과를 볼 때 일정하게 부정적 반응 이 나오는 것으로 나타났으므로 본 연구의 핵 심이 아니라고 판단했기 때문이며 최근 연구인 Campbell and Goodstein(2001)연구 등에서도 일치성의 고, 중에 초점을 맞추고 있다. 불일치 가 중간정도인지는 조작점검을 통해 확인하고 자 하였다.

실험대상 제품은 $\mathrm{C}$ 대학의 대학원생을 대상으 로 한 사전조사와 기존 연구(Voss, Spangenberg and Grohmann 2003)를 기초로 제품 자체에 지각된 위헙이 내재되어 있지 않으면서 기능적 인 제품으로 오렌지 주스 감성적인 제품으로 컴퓨터 게임올 선정하였다

응답자는 C대학 학부생 2-4학년 대학생 240 명을 대상으로 하였다. 실험에 사용된 브랜드는 사전조사를 통해 선점하였는데 실험에 활용된 유통업체는 다수의 유통업자 브랜드를 가지고 있으면서 널리 알려진 이마트를 선정하였으며 오렌지 주스의 소재 브랜드로는 델몬트와 농협 을 사용하였다. 델몬트는 제품과 일치성이 높은 브랜드로 농협은 일치성이 중간정도인 브랜드 로 사용하였다. 그리고 컴퓨터 게임의 소재브랜 드는 대학생들에게 게임 제조회사로 유명한 블 리자드를 활용하였다. 


\section{2 실험절차 및 측정도구}

240명의 실험 대상자들을 〈표 4-1〉의 실험설 계를 기준으로 무작위로 할당하여 실헙자극을 제시하고 설문을 통해 반응을 조사하였다. 먼저 〈표 4-1〉의 각 셀에 할당된 응답자들에게 각각 의 시나리오를 접하도록 하였다. 기능적 위헙이 큰 시나리오로는 응답자가 질병이 있어 병원에 갔는데 진료 의사가 비타민을 충분히 섭취할 것을 조언하고 오렌지 주스를 지속적으로 마실 것을 이야기하여 응답자가 할인점에 가서 오렌 지 주스를 구매하는 상황을 생각하도록 하였 다. 그리고 기능적 위험이 낮은 상황은 응답자 가 제품을 판매하는 기업의 시장조사에 응답 하는 상황을 생각하도록 하였다(Campbell and Goodstein 2002). 감성적 제품의 경우에도 시장 조사 상황을 생각하고 응답하도록 하였다. 오렌 지 주스의 실험자극은 이마트 오렌지 주스, 이 마트 컴퓨터 게임, '이마트 오렌지 쥬스 - 델몬 트가 원료를 제공합니다.' '이마트 컴퓨터 게임 -블리자드가 지원합니다.' 라고 자극을 제시하 였으며 실제 상황을 생각하도록 하기 위해 품 질의 우수성 등을 공통적인 자극으로 제시하였 다. 응답자들은 시나리오와 실헙 자극을 1 분 정 도 본 후에 응답자들이 접한 제품의 지각된 품
질 3 문항과 구매의도 1 문항으로 답하였다. 이 답을 할 때는 다시 자극물을 보지 않도록 하였 다. 그리고 조작 점검을 위하여 소재브랜드와 제품의 일치성 정도 1 문항, 기능적 위헙 3 문항, 기능적 제품 4 문항, 감성적 제품 4 문항에 대하 여 답하도록 하였다. 일치성 척도는 9점 척도를 사용하였으며 나머지 측정 도구들은 7점 척도 를 사용하였다.

본 연구에서 사용한 기능적 위험은 기대했던 효과가 없을까 봐 염려됨, 사용 후 결과가 염 려됨, 효과가 있을 지 신경 쓰임의 3문항으로 측정하였다. 그리고 기능적 제품과 감성적 제 품을 점검하는 질문은 Voss, Spangenberg, and Grohmann(2003)의 연구에서 개발한 기능적 제 품, 감성적 제품 측정 척도를 활용하였다. 의미 차별화 척도로 기능적 측면은 '기능적이다', '필 요하다', '실용적이다', '도움이 된다'로 측정하였 고 감성적 측면은 재미, 흥미, 즐거움, 스릴로 측정하였다. 그리고 지각된 품질과 구매의도는 Campbell and Goodstein(2001)의 연구에서 개 발한 척도를 사용하였는데 지각된 품질은 '품질 이 좋을 것이다', '품질에 만족할 것이다', '품질 에 신뢰가 간다'로 측정하였고 구매의도는 '상 품을 사고 싶은 마음으로 측정하였다.

〈표 4-1〉 본 연구의 실험설계

\begin{tabular}{|c|c|c|c|c|c|c|}
\hline & 제품유형 & \multicolumn{3}{|c|}{ 기능적 제품 } & \multicolumn{2}{|c|}{ 감성적 제품 } \\
\hline & & \multicolumn{2}{|c|}{ 소재 브랜드 유 } & \multirow{3}{*}{$\begin{array}{c}\text { 소재 } \\
\text { 브랜드 무 }\end{array}$} & \multirow{3}{*}{ 소재 브랜드 유 } & \multirow{3}{*}{ 소재 브랜드 무 } \\
\hline & & \multicolumn{2}{|c|}{ 기능적 위험 } & & & \\
\hline & & 고 & 저 & & & \\
\hline \multirow{2}{*}{ 일치성 } & 고 & 집단 1 & 집단 2 & \multirow{2}{*}{ 집단 5} & \multirow{2}{*}{ 집단 6} & \multirow{2}{*}{ 집단 7} \\
\hline & 중 & 집단 3 & 집단 4 & & & \\
\hline
\end{tabular}




\section{V. 연구결과 및 토의}

본 연구의 실헙에는 총 240 명의 학부생이 참 여하였는데 응답자 중 적절하지 못한 설문서 를 제외하고 총 233 부가 분석에 활용되었다. 〈표 4-1〉의 각 집단별 응답자의 숫자는 집단1 33 명, 집단2 32 명, 집단3 31 명, 집단4 31 명, 집 단 533 명, 집단 6 에 38 명, 집단 7 에 35 명이었다.

\section{1 신뢰성 검증 및 조작점검}

본 연구에서는 주요 측정도구에 대하여 크론 바 알파 테스트를 통하여 신뢰성을 점검하였는 데 품질 3 문항은 8022 였으며 기능적 제품을 점 검하는 문항 4 문항 중 첫 번째 문항이 제거되 었고 그 후의 알파 계수가 .9022였다. 그리고 감성적 제품을 점검하는 문항은 모두 채택되었 는데 알파 계수가 .9145 였다. 그리고 지각된 위 험을 점검하는 3 문항은 모두 채택되었는데 알 파 계수가 .9043 이었다. 구매의도와 일치성에 관한 질문은 단일문항으로 측정되었다. 이러한 결과를 볼 때 본 연구에서 사용된 측정도구는 신뢰성이 있다고 할 수 있다.

그리고 실헙의 적절한 조작 여부를 점검하였 는데 소재브랜드가 해당 제품과 일치하는 정도 가 높은 경우와 중간인 경우로 조작하여 소재 브랜드를 제시하였는데 이에 대한 조작 점검을 t-test를 통해 실시한 결과 일치성올 높게 조작 한 집단과 중간으로 조작한 집단의 평균 차이 (5.66. 4.43)는 유의한 것으로 나타났다 $(\mathrm{t}=3.59$, $\mathrm{p}=.000$ ). 그리고 일치성 정도를 중간으로 조작 한 집단의 평균이 9점 척도에서 4.43으로 나타
나 적절하게 조작된 것으로 나타났다. 그리고 기능적 위험에 대한 조작 점검 결과 기능적 위 헙이 높은 집단과 낮은 집단의 평균차이 4.89 , $3.23)$ 는 유의한 것으로 나타났다 $(t=10.22, p=$ 0.000 ). 기능적 제품과 감성적 제품으로 적절하 게 조작되었는지 점검하였는데 기능적 제품에 대한 질문에 대해서는 기능적 제품과 감성적 제품의 평균차이(4.20, 3.60)가 유의한 것으로 나타났다 $(t=3.905, p=.000)$. 감성적 제품에 대 한 질문의 평균차이 $(3.66,4.09)$ 도 유의한 것으 로 나타났다 $(\mathrm{t}=-2.29, \mathrm{p}=0.023)$.

\section{2 가설검증 결과}
5.2.1 기능적-감성적 제품과 소재 브랜드 유-무에 따른 소비자 반응

본 연구의 가설검증은 분산분석을 사용하였는 데 먼저 가설 1, 2를 검증하였다. 독립변수는 기능적, 감성적 제품과 소재 브랜드의 유무였으 며 종속변수는 지각된 품질과 구매의도였다. 두 독립변수의 상호작용의 유의성도 점검하였다. 먼저 지각된 품질을 종속변수로 한 분석결과 독립변수의 평균과 분산은 〈표 5-1〉과 같다.

종속변수를 지각된 품질로 했을 때의 분산분 석 결과는 〈표 5-2〉와 같다. 분산분석의 전체적 인 모형은 $\mathrm{F}=4.461, \mathrm{p}=.005$ 로 유의하게 나타 넜으며 기능적 제품과 감성적 제품의 차이는 $\mathrm{F}=3.855, \mathrm{p}=.051$ 이었으며 소재 브랜드의 유무 차이는 $\mathrm{F}=6.269, \mathrm{p}=.013$ 이었다. 기능-감성제 품. 소재 브랜드 유-무의 상호작용 효과는 $\mathrm{F}=$ .328. $\mathrm{p}=.567$ 이었다. 이 결과를 볼 때 기능적감성적 제품에 따라 지각된 품질이 차이나는 
〈표 5-1〉 종속변수가 지각된 품질 일 때의 기능감성제품. 소재 브랜드 유-무의 평균

\begin{tabular}{|c|c|c|c|c|}
\hline & 소재브랜드 유 무 & 평 균 & 표준편차 & 응답자 수 \\
\hline \multirow{3}{*}{ 기능적 제품 } & 소재 브랜드 유 & 3.97 & .8644 & 127 \\
\cline { 2 - 5 } & 소재 브랜드 무 & 3.68 & .8274 & 33 \\
\hline \multirow{2}{*}{ 감성적 제품 } & 소재 브랜드 유 & 3.76 & 1.1609 & 38 \\
\cline { 2 - 5 } & 소재 브랜드 무 & 3.30 & 1.2959 & 35 \\
\hline
\end{tabular}

〈표 5-2〉 기능적-감성적 제품. 소재브랜드 유무의 분산분석 결과(종속변수: 지각된 품질)

\begin{tabular}{|l|r|r|r|r|c|}
\hline & 제곱합 & 자유도 & 평균제곱 & F & 유의확률 \\
\hline 수정모형 & 13.035 & 3 & 4.345 & 4.461 & $.005^{* * *}$ \\
\hline 절편 & 2327.449 & 1 & 2327.449 & 2389.7 & .000 \\
\hline 기능적 제품*감성적 제품 & 3.754 & 1 & 3.754 & 3.855 & $.051^{*}$ \\
\hline 소재 브랜드 유*무 & 6.105 & 1 & 6.105 & 6.269 & $.013^{* *}$ \\
\hline 상호작용 효과 & .320 & 1 & .320 & .328 & .567 \\
\hline 오 차 & 223.031 & 229 & .974 & & \\
\hline 합 계 & 3593.750 & 233 & & & \\
\hline
\end{tabular}

${ }^{*} \mathrm{p}<.1{ }^{* *} \mathrm{p}<.05,{ }^{* * *} \mathrm{p}<.01$

것은 유의수준 .1에서 유의한 것으로 나타났으 며 소재브랜드 유-무에 따른 차이는 유의수준 .05에서 유의하였다. 하지만 상호작용 효과는 유의하지 않은 것으로. 나타났다.

종속변수를 구매의도로 하였을 때의 평균과 표준편차는 〈표 5-3〉과 같이 나타났다. 분산분 석의 전체적인 모형은 $\mathrm{F}=5.229, \mathrm{p}=.002$ 로 유 의하게 나타났으며 기능적 제품과 감성적 제품 의 차이는 $\mathrm{F}=7.642, \mathrm{p}=.006$ 이었으며 소재 브 랜드의 유무 차이는 $F=4.213, p=.041$ 이었다. 기능-감성제품, 소재 브랜드 유-무의 상호작용 효과는 $\mathrm{F}=4.644, \mathrm{p}=032$ 이었다. 이 결과를 볼 때 기능적-감성적 제품과 소재 브랜드 유-무에 따른 차이는 유의한 것으로 나타났다. 그리고 상호작용 효과도 유의한 것으로 나타났다.
이상과 같은 결과를 볼 때 유통업자 브랜드가 제조업자 브랜드를 소재브랜드로 사용하면 전 반적으로 지각된 품질과 구매의도가 전반적으 로 상승하는 것을 발견할 수 있다. 따라서 가설 1은 채택되었다고 할 수 있다. 하지만 〈표 5-3〉 에서 보는 것처럼 기능적 제품의 경우는 지각 된 품질은 상승했지만 구매의도는 증가하지 않 는 것으로 나타났다. 이 결과에 대해서는 추가 적인 연구가 필요하겠지만 기능적 제품에서 소 재브랜드로 사용된 제조업자 브랜드가 지각된 품질을 높이는 데는 직접적인 영향을 주지만 구매의도로 연결되는 데는 제품속성별로 구체 적 정보처리를 하는 기능적 제품의 성격상 다 른 소비자 특성이나 제품특성이 영향을 줄 수 있다는 것을 시사한다. 
〈표 5-3〉 종속변수가 구매의도 일 때의 기능감성제품. 소재 브랜드 유무의 평균

\begin{tabular}{|c|c|c|c|c|}
\hline & 소재브랜드 유 무 & 평균 & 표준편차 & 응답자 수 \\
\hline \multirow{2}{*}{ 기능적 제품 } & 소재 브랜드 유 & 3.53 & 1.1186 & 127 \\
\cline { 2 - 5 } & 소재 브랜드 무 & 3.55 & 1.1750 & 33 \\
\hline \multirow{2}{*}{ 감성적 제품 } & 소재 브랜드 유 & 3.42 & 1.0301 & 38 \\
\cline { 2 - 5 } & 소재 브랜드 무 & 2.69 & 1.3234 & 35 \\
\hline
\end{tabular}

〈표 5-4〉 기능적-감성적 제품. 소재브랜드 유무의 분산분석 결과(종속변수: 구매의도)

\begin{tabular}{|l|c|c|c|c|c|}
\hline & 제곱합 & 자유도 & 평균제곱 & $F$ & 유의확률 \\
\hline 수정모형 & 20.595 & 3 & 6.865 & 5.229 & $.002^{* * *}$ \\
\hline 절편 & 1866.523 & 1 & 1866.523 & 1421.74 & .000 \\
\hline 기능적 제품*감성적 제품 & 10.032 & 1 & 10.032 & 7.642 & $.006^{* * *}$ \\
\hline 소재 브랜드 유*무 & 5.531 & 1 & 5.531 & 4.213 & $.041^{* *}$ \\
\hline 상호작용 효과 & 6.096 & 1 & 6.096 & 4.644 & $.032^{* *}$ \\
\hline 오 차 & 300.641 & 229 & 1.313 & & \\
\hline 합 계 & 2993.0 & 233 & & & \\
\hline
\end{tabular}

${ }^{* *} \mathrm{p}<.05,{ }^{* * *} \mathrm{p}<.01$

그리고〈표 5-1〉 〈표 5-4〉 에서 보는 것처럽 기능적 제품이냐 감성적 제품이냐에 따라서 소재 브랜드 효과가 달라지지는 않는 것으로 나타났 다. 따라서 가설 2는 기각되었다. 이러한 결과가 나타난 것은 소비자들이 제품을 평가할 때 소재 브랜드를 제품 속성과 가까운 단서로 사용한 것 이 아니라 일반 브랜드나 원산지처럼 2차적 단서 로 사용했기 때문인 것으로 생각할 수 있으며 유 통업자 브랜드는 감성적 제품에 대해서도 품질의 보완을 요구하고 있는 것으로도 볼 수 있다.

5.2 .2 기능적 위험과 일치성 정도에 따른 소비자 반응

본 연구에서는 가설 3,4 를 검증하기 위해서
기능적 제품에서 유통업자 브랜드가 제조업자 소재 브랜드를 사용하였을 때의 소비자 반응을 분산분석을 통해 분석하였다. 독립변수는 기능 적 위헙 고, 저와 일치성 고, 중이었으며 종속 변수는 지각된 품질과 구매의도였다. 두 독립변 수의 상호작용의 유의성도 분석하였다.

첫째, 기능적 위험이 높을 때 소재 브랜드로 사용된 제조업자 브랜드와 제품간의 일치성 정 도가 소비자 반응에 미치는 영향을 분석하였다. 〈표 5-6〉에 나타난 바와 같이 지각된 품질올 종속변수로 한 분산분석은 일치성 효과가 유의 한 것 $(\mathrm{F}=11.945, \mathrm{p}=.001)$ 으로 나타났으며 기 능적 위험이 클 때는 일치성이 높은 경우가 일 치성이 중간인 경우보다 소비자들의 지각된 품 질이 높게 나타났다. 〈표 5-7〉의 구매의도를 종 
〈표 5-5〉 기능적 위험이 높을 때의 일치성에 따른 소비자 반응 평균

\begin{tabular}{|c|c|c|c|}
\hline 종속변수 & 일치성 & 평균 & 응답자 수 \\
\hline \multirow{2}{*}{ 지각된 품질 } & 일치성 고 & 4.45 & 33 \\
\cline { 2 - 4 } & 일치성 중 & 3.67 & 32 \\
\hline \multirow{2}{*}{ 구매의도 } & 일치성 고 & 3.70 & 33 \\
\cline { 2 - 4 } & 일치성 중 & 2.75 & 32 \\
\hline
\end{tabular}

〈표 5-6〉 기능적 위험이 높을 때 일치성 고-중에 따른 분산분석 결과(종속변수: 지각된 품질)

\begin{tabular}{|c|c|c|c|c|c|}
\hline & 제곱합 & 자유도 & 평균제곱 & $\mathrm{F}$ & 유의확률 \\
\hline 집단간 & 9.952 & 1 & 9.952 & 11.945 & $.001^{* * *}$ \\
\hline 집단내 & 52.487 & 63 & .833 & & \\
\hline 합 계 & 62.438 & 64 & & & \\
\hline
\end{tabular}

*** $\mathrm{p}<.01$

〈표 5-7〉 기능적 위험이 높을 때 일치성 고-중에 따른 분산분석 결과(종속변수: 구매의도)

\begin{tabular}{|c|c|c|c|c|c|}
\hline & 제곱합 & 자유도 & 평균제곱 & $\mathrm{F}$ & 유의확률 \\
\hline 집단간 & 14.569 & 1 & 14.569 & 10.802 & $.002^{* * *}$ \\
\hline 집단내 & 84.970 & 63 & 1.349 & & \\
\hline 합 계 & 99.538 & 64 & & & \\
\hline
\end{tabular}

*** $\mathrm{p}<.01$

〈표 5-8〉 기능적 위험이 낮을 때의 일치성에 따른 소비자 반응

\begin{tabular}{|c|c|c|c|}
\hline 종속변수 & 일치성 & 평균 & 응답자 수 \\
\hline \multirow{2}{*}{ 지각된 품질 } & 일치성 고 & 3.68 & 31 \\
\cline { 2 - 4 } & 일치성 중 & 4.06 & 31 \\
\hline \multirow{2}{*}{ 구매의도 } & 일치성 고 & 3.55 & 31 \\
\cline { 2 - 4 } & 일치성 중 & 4.00 & 31 \\
\hline
\end{tabular}

속변수로 한 분석에서도 일치성 호과는 유의한 것 $(F=10.802, p=.002)$ 으로 나타났으며 일치성 이 높은 경우에 구매의도가 높게 나타났다.

둘째, 기능적 위험이 낮은 경우에 소재브랜드 로 사용된 제조업자 브랜드와 제품의 일치성 정도에 따라 소비자 반응이 어떻게 달라지는
지 분석하였다. 〈표 5-9〉와 같이 지각된 품질을 종속변수로 하였을 때 일치성 효과는 유의한 것 $(\mathrm{F}=4.95, \mathrm{p}=.030)$ 으로 나타났으며 기능적 위헙이 낮은 경우에는 일치성이 높은 경우보다 일치성이 중간인 경우에 지각된 품질이 더 높 은 것으로 나타났다. 
〈표 5-9〉 기능적 위험이 낮율때 일치성 고-중에 따른 분산분석 결과(종속변수: 지각된 품질)

\begin{tabular}{|c|c|c|c|c|c|}
\hline & 제곱합 & 자유도 & 평균제곱 & $\mathrm{F}$ & 유의확률 \\
\hline 집단간 & 2.323 & 1 & 2.323 & 4.951 & $.030^{* *}$ \\
\hline 집단내 & 28.145 & 60 & .469 & & \\
\hline 합 계 & 30.468 & 61 & & & \\
\hline
\end{tabular}

** $\mathrm{p}<.05$

〈표 5-10〉 기능적 위험이 낮울 때 일치성 고-중에 따른 분산분석 결과(종속변수: 구매의도)

\begin{tabular}{|c|c|c|c|c|c|}
\hline & 제곱합 & 자유도 & 평균제곱 & $\mathrm{F}$ & 유의확률 \\
\hline 집단간 & 3.161 & 1 & 3.161 & 6.391 & $.014^{* *}$ \\
\hline 집단내 & 29.677 & 60 & .495 & & \\
\hline 합 계 & 32.839 & 61 & & & \\
\hline
\end{tabular}

** $\mathrm{p}<.05$

그리고 〈표 5-10)과 같이 구매의도가 종속변 수 일 때도 일치성 효과는 유의한 것으로 나타 났으며 $(\mathrm{F}=6.391, \mathrm{p}=.014)$ 기능적 위헙이 낮을 때는 일치성 높은 경우보다 일치성이 중간인 경우에 구매의도가 더 높은 것으로 나타났다.

그리고 기능적 위헙 저-고, 일치성 고-중을 독립변수로 하고 지각된 품질과 구매의도를 종 속변수로 하여 이원 분산분석을 실시하였는데 그 결과는〈표 5-11〉, 〈표 5-12〉와 같다. 〈표
5-11〉과〈표 5-12〉를 보면 상호작용 효과가 모 두 유의하게 나타났는데 이는 〈표 5-6〉. 〈표 $5-7\rangle,\langle 5-9\rangle,\langle 5-10\rangle$ 의 결과를 확인해 주고 있 다. 이상과 같은 결과는 가설 3 과 가설 4 의 결 과를 지지하는 것이다

이상과 같은 결과는 소비자가 기능적 제품을 구매할 때 기능적 위헙이 크게 되면 제조업자 브랜드와 제품의 일치성이 높올 때 더 긍정적 인 반응을 나타낸다는 것을 보여준 것이다. 반

〈표 5-11〉 기능적 위험 저-고, 일치성 고-중 일 때 이원분산분석 결과(종속변수: 지각된 품질)

\begin{tabular}{|l|r|r|r|r|c|}
\hline & 제곱합 & 자유도 & 평균제곱 & \multicolumn{1}{|c|}{$F$} & 유의확률 \\
\hline 수정모형 & 13.522 & 3 & 4.507 & 6.876 & .000 \\
\hline 절편 & 1997.354 & 1 & 1997.354 & 3046.874 & .000 \\
\hline 기능적 위헙 저*고 & 1.173 & 1 & 1.173 & 1.789 & .184 \\
\hline 일치성 고*중 & 1.241 & 1 & 1.241 & 1.893 & .171 \\
\hline 기능적 위험 저고*일치성 고중 & 10.854 & 1 & 10.854 & 16.557 & $.000^{* * *}$ \\
\hline 오 차 & 80.632 & 123 & .656 & & \\
\hline 합 계 & 2098.250 & 127 & & & \\
\hline
\end{tabular}

${ }^{* * *} \mathrm{p}<.01$ 
〈표 5-12〉 기능적 위험 저-고, 일치성 고-중 일 때 이원분산분석 결과(종속변수:구매의도)

\begin{tabular}{|l|r|r|r|r|c|}
\hline & 제곱합 & 자유도 & 평균제곱 & F & 유의확률 \\
\hline 수정모형 & 27.101 & 3 & 9.034 & 9.692 & .000 \\
\hline 절편 & 1553.671 & 1 & 1553.671 & 1666.867 & .000 \\
\hline 기능적 위험 저*고 & 9.623 & 1 & 9.623 & 10.324 & $.002^{* * *}$ \\
\hline 일치성 고*중 & 1.946 & 1 & 1.946 & 2.088 & .151 \\
\hline 기능적 위헙 저고*일치성 고중 & 15.516 & 1 & 15.516 & 16.646 & $.000^{* * *}$ \\
\hline 오 차 & 114.647 & 123 & .932 & & \\
\hline 합 계 & 1694.0 & 127 & & & \\
\hline
\end{tabular}

${ }^{* * *} \mathrm{p}<.01$

면에 기능적 위헙이 낮을 때에는 일반적인 중 간일치성 효과가 나타남을 보여준 것이다. 따라 서 이 결과는 기존 Meyers-Levy and Tybout (1989), Peracchio and Tybout(1996), Campbell and Goodstein(2001)의 연구에서 발견한 독단 성, 사전지식, 사회적 위험이 중간일치성 효과 의 조절변수 역할을 한다는 결과에 추가적인 변수인 기능적 위헙의 역할을 밝힌 것이라고 할 수 있다. 즉, 제조업자 브랜드가 유통업자 브랜드의 소재브랜드로 사용될 경우에 제조업 자 브랜드와 제품의 일치성 정도에 딴른 소비 자 반응은 기능적 위험에 영향을 반아 중간일 치성 효과의 방향이 바뀔 수 있음을 보여준 것 이다. 이처럼 지각된 위험의 여러 종류는 제품 과 사용 형태에 따라 중간 일치성 효과의 조절 변수 역할을 할 수 있을 것이다.

\section{VI. 결론 및 시사점}

김현경, 이문규(2003)의 연구에서 보는 바와
같이 브랜드 간 제휴는 여러 형태가 있을 수 있고 소비자들의 반응도 다양하게 나타날 수 있다. 그러나 본 연구에서는 성장의 한계를 가 지고 있는 유통업자 브랜드가 제조업자 브랜드 를 소재 브랜드로 사용하였을 때로 브랜드 제 휴의 범위를 국한해서 살펴보았다. 연구결과 유 통업자 브랜드가 제조업자 브랜드와 제휴를 한 다면 한계를 극복하고 긍정적인 소비자 반응을 얻을 수 있는 것으로 나타났다. 하지만 유통업 자 브랜드가 제조업자 브랜드를 소재브랜드로 사용할 때 기능적 제품이 감성적 제품보다 더 큰 효과를 누리지는 않는 것으로 나타났다. 그 러나 제조업자 브랜드가 유통업자 브랜드의 소 재 브랜드로 사용되어 기능적 제품에 사용될 때는 중간 일치성 효과가 나타났는데 이 때 기 능적 위험이 조절변수 역할을 하는 것으로 나 타났다.

본 연구는 유통업자 브랜드와 제조업 브랜드 의 제휴 효과를 소재 브랜드, 기능적-감성적 제 품, 일치성에 따라 이론적, 실증적으로 설명했 다는 점에서 의의가 있다고 할 수 있다. 과거 연구에서 간과되었던 소재 브랜드 효과. 공동 
브랜드 효과의 기능적, 감성적 제품에 따른 차 이를 연구하였다. 그리고 중간 일치성 효과를 유통업자 브랜드와 제조업자 브랜드 제휴에 적 용하였다는 점에서 의의가 있다. 그리고 중간 일치성 효과의 조절변수로 새로운 변수인 기능 적 위헙의 역할을 밝혔다는 점에서 의미가 있 다고 할 수 있다. 실무적으로도 성장 한계에 처 해 있는 유통업자 브랜드가 돌파구를 마련할 수 있는 전략적 대안으로 제조업자 브랜드를 소재브랜드로 활용하여 성장할 수 있다는 가능 성을 확인했다는 측면에서 의의가 크다고 할 수 있다. 그리고 제휴 전랴 실행 시에도 어떤 브랜드와 제휴하는 것이 효과적인가에 대한 이 론적 시사점을 제시했다는 측면에서 의의가 있 다고 할 수 있다.

하지만 본 연구는 여러 브랜드 제휴 유형 중 에서 유통업자와 제조업자 제휴에 국한되어 있 으며 그 중에서도 소재 브랜드 상황만을 전제 하고 있으므로 향후 연구에서 보다 다양한 형 태의 제휴를 연구하는 것이 필요할 것이다. 그 리고 본 연구의 결과 전반적인 소비자 반응이 높게 나타나지 않았는데 이는 주브랜드와 보조 브랜드의 영향력에 차이가 있기 때문인 것으로 보인다. 따라서 향후 연구에서는 추가적인 연구 가 필요할 것으로 보인다. 그리고 본 연구에서 사용한 제품의 종류는 제한적이기 때문에 일반 화를 위해서 다양한 제품 유형에서 소비자 반 응을 분석하는 것이 필요할 것이다. 지각된 위 험에서 사회적. 기능적, 경제적 위헙 등은 제품 유형과 상황에 따라 중간일치성 효과의 조절변 수 역할을 하는 것으로 나타났으므로 향후 연 구에서는 각각의 위험이 어떤 제품과 어떤 상 황에서 조절변수 역할을 하는지 추가적인 연구
가 펄요할 것이다. 그리고 본 연구는 주브랜드 효과는 동화. 대조효과로 소재 브랜드 효과는 중간 일치성 효과에 의한 시너지 효과로 설명 했는데 각 상황이 일어나는 원인을 구체적으로 밝히지는 못했다. 이에 대한 추가적인 연구가 필요할 것이다. 그리고 기능적 제품에서만 소재 브랜드의 세밀한 효과를 연구했는데 이는 소재 브랜드가 기능적 제품에서 중요할 것이라는 가 정에서 비롯된 것이었다. 하지만 기능적-감성적 제품에 따라 큰 차이는 없는 것으로 나타났다. 따라서 향후 연구에서 감성적 제품을 대상으로 기능적 위험의 조절효과를 연구하는 것이 필요 할 것이다.

〈논문 접수일: 2004. 3. 15〉

〈게재 확정일: 2004. 4. 21〉

\section{참고문헌}

김성배, 전인수(2002), “유통업체 상표의 지각된 정보단서가 이의 지각품질, 지각희생 및 선 호에 미치는 영향," 유통연구. 제6권 2호. 19-40.

김현경, 이문규(2003), "브랜드 제휴의 유형에 따른 소비자 평가." 경영학연구. 제 32 권 3 호. 875-905.

박진용(2002). "유통업체 브랜드와 제조업체 브 랜드간 전략적 연계에 관한 연구." 한국유

통학혀 추계학술대회 발표논문집. $75-88$. 박진용, 정강옥(2002), "유통업체 브랜드 구매의 도 및 선행변수 관계의 지역간 차이." 마케 팅과확회 춘계학술대혀 발표논문집, 105120. 
Ailawadi, Neslin and Gedenk(2001), "Pursuing the Value-Conscious Consumer: Store Brands Versus National Brand Promotions," Journal of Marketing, 65(January), 71-89.

Campbell and Goodstein(2001), "The Moderating Effect of Perceived Risk on Consumers' Evaluations of Product Incongruity: Preference for the Norm," Journal of Consumer Research, 28(December), 439-449.

Cohen. B. and G. L. Murphy(1984), "Models of Concepts," Cognitive Science, 8(1). 27-58.

Desai, Kalpish Kaushik and Kevin Lane Keller (2002), "The Effects of Ingredient Branding Strategies on Host Brand Extendibility," Journal of Marketing, 66(January), 73-93.

Dhar, Ravi and Klas Wertenbroch(2000), "Consumer Choice Between Hedonic and Utilitarian Goods," Journal of Marketing Research, 37(February), 60-71.

Keller, Kevin Lane(2002), Strategic Brand Management. Upper Saddle River, NJ: Prentice Hall.

Lee, Moonkyu and Francis M. Ulgado(1994), "Alternative Models of Cognitive Processes Underlying Consumer Reactions to Conjunction Categories," Advances in Consumer Research, 21, 483-488.

Mandler, George(1982), "The Structure of Value: Accounting for Taste," in Affect and Cognition: The 17th Annual Carnegie Symposium, M. S. Clark and S.A. Fiske (Eds.), Lawrence Erlbaum Associates,
3-36.

Meyers-Levy, Joan and Alice M. Tybout (1989), "Schema Congruity as a Basis for Product Evaluation," Journal of Consumer Research, 16(June), 39-54.

Park, C. Whan, Sung Youl Jun, and Allan D. Shocker(1996). "Composite Branding Alliances: An Investigation of Extension and Feedback Effects," Journal of Marketing Research. 33(November), 453-466.

Peracchio. Laura A. and Joan Meyers-Levy (1994), "How Ambiguous Cropped objects in Ad Photos Can Affect Product Evaluations," Journal of Consumer Research, 21(June), 190-204.

and Alice M. Tybout(1996),

"The Moderating Role of Prior Knowledge in Schema-Based Product Evaluation," Joumal of Consumer Research, 23(December). 177-192.

Richardson, Dick and Jain(1994), "Extrinsic and Intrinsic Cue Effects on Perceptions of Store Brand Quality," Journal of Marketing, 58(October), 28-36. (1996). "Household Store Brand

Proneness: A Framework," Journal of Retailing, 72(2), 159-185.

Vaidyanathan, Rajiv and Praveen Aggarwal (2000). Strategic Brand Alliances: Implications of Ingredient Branding for National and Private Label Brands, Journal of Product and Brand Management, 9(4). 214-228. 
Venkatesh. R. and Vijay Mahajan(1997), Voss, Kevin E., Eric R. Spangenberg, and "Products with Branded Components: An Approach for Premium Pricing and Partner Selection," Marketing Science, 16. 146-165.

Bianca Grohmann(2003), "Measuring the Hedonic and Utilitarian Dimensions of Consumer Attitude," Journal of Marketing Research. (August). 310-320. 


\title{
Consumer Responses to the Alliance between Private Brands and National Brands -Focused on Ingredient Branding-
}

\author{
Cho, Seong $\mathrm{Do}^{*}$ \\ Jung, Gang $\mathrm{Ok}^{* *}$ \\ Park, Jin Yong***
}

\begin{abstract}
Prior researches related to private brands have mainly focused on the competition between private brands and national brands. But private brands can be allied with national brands to overcome its weak points such as low perceived quality. The purpose of this study is to investigate the consumer responses to the alliance between private brands and national brands. Especially this paper focused on the situation in which national brands are used as ingredient brands to improve the consumers' preference toward private brands.

We hypothesized that using national brands as ingredient brands would improved the consumers' perceived quality and buying intention toward private brands. Also we supposed that when national brands had moderate congruity with product category, consumers' preference would be most positive. And this study examined the moderating effects of functional risk.

Factorial experimental design and scenario method were employed to test the hypotheses. Also we classified the products as utilitarian-hedonic products and compared the effects of ingredient brands on utilitarian products with hedonic products. Empirical results show that when private brands use national brands as ingredient brands, consumer responses become positive. Also when ingredient brands have moderate congruity with products, consumer responses are mast positive. But moderate congruity effect is significant only when functional risk is low.
\end{abstract}

Key words: private brand, ingredient brand, moderate congruity effect, brand alliance, functional risk.

\footnotetext{
* Assistant Professor, Department of Business Administration. Chonnam National University.

** Full time lecturer, Department of Business Administration, Hannam University.

*** Assistant Professor, Department of Distribution Management, Dongeui University.
} 